\title{
Hydroxychloroquine Safety: A Meta-analysis of Randomized Controlled Trials
}

Khalid Eljaaly, PharmD, MS, BCPS, BCIDP ${ }^{1,2}$; Kasim Huseein Alireza, PharmD ${ }^{1}$; Samah

Alshehri, PharmD, MS, BCPS ${ }^{1,2}$; Jaffar A. Al-Tawfiq, MD, FSHEA, FIDSA , $^{3,45}$

${ }^{1}$ Faculty of Pharmacy, King Abdulaziz University, Jeddah, Saudi Arabia

${ }^{2}$ College of Pharmacy, University of Arizona, Tucson, AZ

${ }^{3}$ Infectious Disease Unit, Specialty Internal Medicine, Johns Hopkins Aramco Healthcare,

Dhahran, Saudi Arabia

${ }^{4}$ Department of Medicine, Indiana University School of Medicine, Indianapolis, IN, USA

${ }^{5}$ Department of Medicine, Johns Hopkins University School of Medicine, Baltimore, MD, USA

Running Head: Hydroxychloroquine safety meta-analysis

Corresponding author and address for requests for reprints:

Khalid Eljaaly, PharmD, MS, BCPS, BCIDP

Department of Pharmacy Practice, King Abdulaziz University

P.O. Box 80200, Jeddah, postal code 21589, Saudi Arabia

Tel: +966564362332; Fax: +12 (9666400000). ext: 20675

Email: khalid-eljaaly@live.com; Twitter: http://twitter.com/khalideljaaly

\section{Credit author statement}

Khalid Eljaaly: Conceptualization, Methodology, Data curation, Formal analysis, Funding acquisition, Project administration, Investigation, Resources, Software, Supervision, WritingOriginal draft preparation, Writing- review \& editing. Kasim Huseein Alireza: Data curation, Investigation, Writing- Original draft preparation. Samah Alshehri: Data curation, Investigation, Writing- Original draft preparation, Writing- review \& editing. Jaffar Al-Tawfiq: Conceptualization, Writing- Original draft preparation, Writing- review \& editing.

This is the author's manuscript of the work published in final edited form as:

Eljaaly, K., Alireza, K. H., Alshehri, S., \& Al-Tawfiq, J. A. (2020). Hydroxychloroquine safety: A metaanalysis of randomized controlled trials. Travel Medicine and Infectious Disease.

https://doi.org/10.1016/j.tmaid.2020.101812 
Background: Hydroxychloroquine (HCQ) is currently being examined for COVID-19. No previous meta-analysis has evaluated its side effects versus placebo. We conducted this metaanalysis to compare the safety of HCQ versus placebo.

Methods: Two authors independently searched PubMed and EMBASE databases for randomized controlled trials (RCTs) of adults comparing the adverse events (AEs) of HCQ versus placebo for any indication. Peto odds ratios (Peto ORs) and 95\% confidence intervals (CIs) were calculated based on random-effects models. The heterogeneity $\left(\mathrm{I}^{2}\right)$ was assessed using Cochran's Q test.

Results: Nine RCTs (eight were double-blind) with a total of 916 patients were included. HCQ caused significantly more skin pigmentation than placebo (Peto OR, 4.64; 95\% CI, 1.13 to 19.00; $\mathrm{P}$-value $\left.=0.033 ; \mathrm{I}^{2}=0 \%\right)$. The increase in other AEs did not reach statistical significance: rash (Peto OR, 1.11; 95\% CI, 0.3 to 3.77; P-value=0.03; $\mathrm{I}^{2}=0 \%$ ); gastrointestinal AEs (Peto OR, 1.43; 95\% CI, 0.55 to $3.72 ; \mathrm{P}$-value $=0.46 ; \mathrm{I}^{2}=15.17 \%$ ); headache (Peto OR, $1.94 ; 95 \% \mathrm{CI}, 0.65$ to 5.78; P-value $=0.23 ; \mathrm{I}^{2}=9.99 \%$ ); dizziness (Peto OR, 1.32; 95\% CI, 0.49 to 3.52; P-value=0.58; $\mathrm{I}^{2}=0 \%$ ); fatigue (Peto OR, 2.13; 95\% CI, 0.76 to 5.98; P-value $=0.15 ; \mathrm{I}^{2}=0 \%$ ); and visual AEs (Peto OR, $1.61 ; 95 \%$ CI, 0.76 to $3.41 ; \mathrm{P}$-value=0.22; $\mathrm{I}^{2}=0 \%$ ). Cardiac toxicity was not reported. Conclusions: This meta-analysis of RCTs found a significantly higher risk of skin pigmentation in HCQ users versus placebo. More data are needed to evaluate HCQ in the context of COVID19 treatment. 


\section{INTRODUCTION}

The 4-aminoquinoline compounds such as chloroquine (CQ) and its hydroxylated analog, hydroxychloroquine (HCQ), have been widely used in the treatment of malaria [1]. Additionally, HCQ is an approved treatment for a number of autoimmune diseases such as systemic lupus erythematosus (SLE) and rheumatoid arthritis (RA) [2]. Further observations highlight its potential efficacy in a wide range of conditions, including endocrine diseases, coagulopathies, and infectious diseases [3]. Due to its lower toxicity, HCQ is preferred over CQ in rheumatic conditions. The definite mechanism of action of HCQ in controlling these diseases is unknown. HCQ is thought to work by interfering with lysosomal activity, inhibition presentation of antigens and Toll $\square$ like receptor signaling, and termination of circulating immune complexes [4]. HCQ has a very long half-life due to extensive tissue uptake. It is available only in oral dosage forms and needs to be taken with food to reduce the risk of gastrointestinal adverse reactions [2].

Since there is no specific approved therapy for Coronavirus Disease 2019 (COVID-19) yet, multiple agents with antiviral activity are being used as possible therapies such as HCQ, CQ, remdesivir, and lopinavir-retonavir $[5,6,7,8]$. In addition to its immunomodulatory effects, HCQ has some antiviral activity [6]. Despite being a relatively safe and low-cost drug, HCQ can cause a number of side effects and its toxicity is not well understood, partially due to the limited number of patients (low statistical power) in the published randomized controlled trials (RCTs). Therefore, it is useful to conduct this first meta-analysis pooling of all data on its adverse reactions to better understand its safety compared to placebo. The objective of this study is to compare the side effects of HCQ to placebo through a meta-analysis of RCTs of adults who received hydroxychloroquine. 


\section{METHODS}

This meta-analysis followed the Preferred Reporting Items for Systematic Reviews and Meta-Analyses (PRISMA) guidelines.

\section{Search strategy and selection criteria}

Articles were identified via PubMed, EMBASE, and Cochrane Library bibliographic databases (see Appendix A for search strategy). No restrictions were placed on language or publication date. The searches and data extractions were completed independently by two authors until March 19,2020. Any disagreement in the literature screening or data extraction was resolved through discussion. We included comparative RCTs evaluating safety in adults who received HCQ therapy versus placebo. RCTs that did not report specific adverse events (AEs) were excluded.

\section{Outcomes, data analysis, and risk of bias}

The outcomes of interest were the frequency of AEs. Peto odd ratios (Peto ORs) with 95\% confidence intervals (CIs) were assessed using random-effects models, and heterogeneity $\left(\mathrm{I}^{2}\right)$ was evaluated using Cochran's Q test. We examined the study quality using the Cochrane risk of bias tool for RCTs (low, unclear, or high) [9]. We performed all analyses using the Comprehensive Meta-Analysis Version 3 software (Biostat, Englewood, NJ, USA).

\section{RESULTS}

\section{Search results and study characteristics}

The search process identified 713 articles, and a total of nine RCTs [10-18] were included after screening by title/abstract followed by full text review (Figure 1). This metaanalysis included a total of 916 patients. The characteristics of studies are summarized in Table 
1, and the study quality assessment is summarized in Table 2. Eight RCTs were double-blind [11-18], and one was single-blind [10]. Only three RCTs were funded by drug companies [11, 12, 18]. Studies were conducted on four different continents and included patients with a variety of indications. The average age of patients was over 60 years in only one study [17]. The duration of therapy was $\geq 12$ weeks and the HCQ daily dose ranged between 200 and 400 $\mathrm{mg} /$ day, except in one study, in which $800 \mathrm{mg} /$ day was also used [13].

\section{Study outcomes}

Skin pigmentation occurred significantly more with HCQ than with placebo (Peto OR, 4.64; $95 \%$ CI, 1.13 to $19.00 ; \mathrm{P}$-value $=0.033 ; \mathrm{I}^{2}=0 \%$ ) [Figure 1]. Although there was a numerical increase in the rate of AEs, no statistically significant differences were observed in the rate of rash (Peto OR, 1.11; 95\% CI, 0.3 to 3.77; P-value=0.03; $\mathrm{I}^{2}=0 \%$ ), gastrointestinal AEs (Peto OR, 1.43; $95 \%$ CI, 0.55 to 3.72; P-value $=0.46 ; \mathrm{I}^{2}=15.17 \%$ ), headache (Peto OR, $1.94 ; 95 \%$ CI, 0.65 to 5.78; P-value=0.23; $\mathrm{I}^{2}=9.99 \%$ ), dizziness (Peto OR, 1.32; 95\% CI, 0.49 to 3.52; P-value=0.58; $\mathrm{I}^{2}=0 \%$ ), fatigue (Peto OR, 2.13; 95\% CI, 0.76 to 5.98; P-value $=0.15 ; \mathrm{I}^{2}=0 \%$ ), or visual AEs (Peto OR, 1.61; 95\% CI, 0.76 to 3.41; P-value=0.22; $\mathrm{I}^{2}=0 \%$ ) [Figures S1-6 in Appendix A]. No cardiac toxicity was reported in the studies.

\section{DISCUSSION}

In this study, we evaluated the AEs of long-term use of HCQ, as the use of HCQ had been increasing recently with the current COVID-19 pandemics. In this meta-analysis, we attempted to examine systemic AEs of HCQ based on data from RCTs. To the best of our knowledge, this meta-analysis is the first attempt to examine such AEs in RCTs. One strength in 
this meta-analysis results is the low statistical heterogeneity as measured by $\mathrm{I}^{2}$, which indicates low variability in the effects of intervention being assessed in the different studies. However, it is important to consider that meta-analyses of AEs have some general pitfalls [19]. Therefore, the findings of this meta-analysis should be interpreted with caution.

Of all screened studies, we included 9 RCTs. The included studies were mainly in relation to autoimmune diseases and were superiority studies. In addition, the daily dose of HCQ daily was $200-400 \mathrm{mg} /$ day. The current use of HCQ in COVID-19 is mainly short term, and thus the observed AEs in this study might not occur in patients with COVID-19. We observed no significant increase in the occurrence of visual AEs. However, retinopathy was considered an important AE in long-term users [20].

An important observation in this meta-analysis is the occurrence of skin pigmentation significantly more with HCQ than with placebo. We cannot rule out the possibility of insufficient statistical power to detect statistically significant differences in other AEs. However, we included as many studies as we can by not limiting the inclusion criteria to specific indication to catch all studies reporting AEs of HCQ. Skin darkening is an important AE and potentially a cosmetic problem, as complete resolution is rare. The incidence of HCQ-related skin pigmentation was reported to be $7 \%$ in in patients with SLE and was not dose or duration dependent [21]. However, in one study the occurrence of skin pigmentation occurred after a median duration of 32 months and a median cumulative dose of $361 \mathrm{~g}$ [22]. Since this AE may not occur in some patients receiving HCQ for short duration and the included studies used it for several weeks, it might not be relevant in the context COVID-19 except when used for a prolonged period in prophylaxis, which is currently being investigated [8]. Although the mechanism of development of skin pigmentation is not well characterized, one study indicated that a possible mechanism is 
the presence of both melanin and hemosiderin in the dermis [23]. In addition, a previous study identified multiple risk factors, such as bruising, the use of specific medications (corticosteroid, oral anticoagulants, antiplatelet agents), and the presence of antiphospholipid syndrome [20]. The distribution of skin pigmentation is variable and may involve lower extremities, the face, lips, and the gums [22] and may be in the form of a butterfly [24].

This meta-analysis showed no significant difference in the occurrence of skin rash with HCQ. The occurrence of skin rashes may be a characteristic of the underlying disease. In one study, the occurrence of skin rash was more common in patients who had dermatomyositis (31\%) compared to those with cutaneous lupus erythematosus (3\%) [25]. Skin rash was also common in patients with psoriasis and psoriatic arthritis [26]. The included studies in this metaanalysis did not include patients with these underlying diagnoses.

The occurrence of prolonged QTc interval was described in patients receiving HCQ, and discontinuation of HCQ shortened the QTc interval [27, 28]. Another potential cardiotoxicity is the occurrence of cardiomyopathy, and this was linked to older age, female gender, $>10$ years of therapy, high daily dose, and underlying cardiac disease and renal disease [29]. However, the occurrence of QT prolongation and cardiomyopathy were not reported in the included studies. There is concern about arrhythmias in patients with rheumatoid diseases treated with HCQ [30]. However, the included studies did not report on the occurrence of arrhythmias. Indeed, the references to cardiac toxicity included hydroxychloroquine overdoses or suicide attempts. Unfortunately, hydroxychloroquine and chloroquine in particular, are known to have been widely used in suicide attempts. Additionally, and because HCQ could prolong QTc, caution and ECG monitoring are required when using it, particularly in combination with other QTcprolonging medications $[2,7]$. 
Chloroquine and HCQ are metabolized by the hepatic cytochrome P450 enzyme 2D6 (CYP2D6). CYP2D6 expression is variable depending on genetic polymorphisms, and 7\% of white North Americans have no functional CYP2D6 "poor metabolizer" and 1-2\% have gene duplications conferring an "ultrarapid metabolizer" phenotype. The variation in CYP2D6 may also influence the variability of AEs [30]. Glucose-6-phosphate dehydrogenase deficiency, which is associated with hemolysis after using some antimalarial drugs, seems to be of less concern with HCQ [31].

In conclusion, this meta-analysis showed that skin pigmentation was the only significant AE of HCQ compared to placebo. However, the included studies mainly evaluated the use of CHQ in the treatment of autoimmune diseases and did not include the full spectrum of these abnormalities. There are certain AEs that might be secondary to the underlying condition and might not be observed in other conditions. The use of HCQ in COVID-19 is an important new development for this drug, and further analysis is needed to specifically address AEs in this population as well as to establish the efficacy. 


\section{Acknowledgement}

This project was funded by the Deanship of Scientific Research (DSR) at King Abdulaziz University, Jeddah, under grant no. GCV19-28-1441. The authors, therefore, acknowledge with thanks DSR for technical and financial support. 


\section{REFERENCES}

1- Lawrenson AS, Cooper DL, O'Neill PM, Berry NG. Study of the antimalarial activity of 4aminoquinoline compounds against chloroquine-sensitive and chloroquine-resistant parasite strains. J Mol Model. 2018 Aug 17;24(9):237.

2- PLAQUENIL® (hydroxychloroquine sulfate) [package insert]. Barbados: Concordia Pharmaceuticals Inc; 2018.

3- Olsen NJ, Schleich MA, Karp DR. Multifaceted effects of hydroxychloroquine in human disease. Semin Arthritis Rheum. 2013;43 (2):264-272.

4- Wallace DJ, Gudsoorkar VS, Weisman MH, Venuturupalli SR. New insights into mechanisms of therapeutic effects of antimalarial agents in SLE. Nat Rev Rheumatol 2012;8:522-33.

5- Eljaaly K, Al-Tawfiq JA. Crushing lopinavir-ritonavir tablets may decrease the efficacy of therapy in COVID-19 patients. Travel Med Infect Dis 2020 May 28:101749. doi: 10.1016/j.tmaid.2020.101749. Online ahead of print.

6- Alhazzani, W., Møller, M.H., Arabi, Y.M. et al. Surviving Sepsis Campaign: guidelines on the management of critically ill adults with Coronavirus Disease 2019 (COVID-19). Intensive Care Med 2020;46:854-887.

7- Bhimraj A, Morgan RL, Shumaker AH, et al. Infectious Diseases Society of America Guidelines on the treatment and mnagement of patients with COVID-19. Clin Infect Dis. 2020. doi: $10.1093 / \mathrm{cid} / \mathrm{ciaa} 478$.

8- Qaseem A, Etxeandia-Ikobaltzeta I, Miller MC, et al. Should clinicians use chloroquine or hydroxychloroquine alone or in combination with azithromycin for the prophylaxis or 
treatment of COVID-19? Living practice points from the American College of Physicians (Version 1). Ann Intern Med 2020; doi: 10.7326/M20-1998.

9- Higgins J, Altman D, Sterne J. Chapter 8: Assessing risk of bias in included studies In: Higgins JPT, Green S eds. Cochrane handbook for systematic reviews of interventions version 5.1.0. The Cochrane Collaboration. 2011. Available from: http://www.cochranehandbook.org.

10- Boonpiyathad T and Sangasapaviliya A. Hydroxychloroquine in the treatment of antihistamine refractory chronic spontaneous urticaria, randomized single-blinded placebocontrolled trial and an open label comparison study. Eur Ann Allergy Clin Immunol. 2017;49:220-224.

11- Clark P, Casas E, Tugwell P, Medina C, Gheno C, Tenorio G and Orozco JA. Hydroxychloroquine compared with placebo in rheumatoid arthritis. A randomized controlled trial. Ann Intern Med. 1993;119:1067-71.

12- HERA. A randomized trial of hydroxychloroquine in early rheumatoid arthritis: the HERA Study. Am J Med. 1995;98:156-68.

13- Kavanaugh A, Adams-Huet B, Jain R, et al. Hydroxychloroquine effects on lipoprotein profiles (the HELP trial): A double-blind, randomized, placebo-controlled, pilot study in patients with systemic lupus erythematosus. J Clin Rheumatol. 1997;3(1):3-8.

14- Lee W, Ruijgrok L, Boxma-de Klerk B, et al. Efficacy of hydroxychloroquine in hand osteoarthritis: A randomized, double-blind, placebo-controlled trial. Arthritis Care Res (Hoboken). 2018;70(9):1320-1325. 
15- Liu J, Cao R, Xu M, Wang X, Zhang H, Hu H, Li Y, Hu Z, Zhong W and Wang M. Hydroxychloroquine, a less toxic derivative of chloroquine, is effective in inhibiting SARS CoV-2 infection in vitro. Cell Discovery. 2020;6:16.

16- Paton NI, Lee L, Xu Y, Ooi EE, Cheung YB, Archuleta S, Wong G and Wilder-Smith A. Chloroquine for influenza prevention: a randomised, double-blind, placebo controlled trial. Lancet Infect Dis. 2011;11:677-83.

17- Van Gool WA, Weinstein HC, Scheltens P and Walstra GJ. Effect of hydroxychloroquine on progression of dementia in early Alzheimer's disease: an 18-month randomised, doubleblind, placebo-controlled study. Lancet. 2001;358:455-60.

18- Yokogawa N, Eto H, Tanikawa A, et al. Effects of hydroxychloroquine in patients with cutaneous lupus erythematosus: A multicenter, double-blind, randomized, parallel-group trial.

19- Proano C, Kimball GP. Hydroxychloroquine retinal toxicity. N Eng; J Med 2019;380(17):e27.

20- Han-Yao Huang, Elizabeth Andrews, Judith Jones, et al. Pitfalls in meta-analyses on adverse events reported from clinical trials. Pharmacoepidemiol Drug Saf 2011;20(10):1014-20.

21- Jallouli M, Francès C, Piette JC, et al. Hydroxychloroquine-induced pigmentation in patients with systemic lupus erythematosus: a case-control study. JAMA Dermatol 2013; 149(8):93540.

22- Bahloul E, Jallouli M, Garbaa S, et al. Hydroxychloroquine-induced hyperpigmentation in systemic diseases: prevalence, clinical features and risk factors: a cross-sectional study of 41 cases. Lupus. 2017;26(12):1304-1308. 
23- Puri PK, Lountzis NI, Tyler W, et al. Hydroxychloroquine-induced hyperpigmentation: the staining pattern. J Cutan Pathol 2008;35(12):1134-7.

24- Pelechas E, Drosos AA. Hydroxychloroquine-induced dark butterfly rash in a rheumatoid arthritis patient. Rheumatology 2018;57(5):849.

25- Pelle MT, Callen JP. Adverse cutaneous reactions to hydroxychloroquine are more common in patients with dermatomyositis than in patients with cutaneous lupus erythematosus. Arch Dermatol 2002;138(9):1231-1233.

26- Slagel GA, James WD. Plaquenil-induced erythroderma. J Am Acad Dermatol 1985;12857862.

27- Newton-Cheh C, Lin AE, Baggish AL, et al. Case records of the Massachusetts General Hospital. Case 11-2011. A 47-year-old man with systemic lupus erythematosus and heart failure. N Engl J Med 2011;364:1450-1460

28- Chen CY, Wang FL and Lin CC. Chronic hydroxychloroquine use associated with QT prolongation and refractory ventricular arrhythmia. Clin Toxicol (Phila) 2006;44:173-175.

29- Joyce E, Fabre A, Mahon N. Hydroxychloroquine cardiotoxicity presenting as a rapidly evolving biventricular cardiomyopathy: key diagnostic features and literature review. Eur Heart J Acute Cardiovasc Care 2013;2(1):77-83.

30- Radke JB, Kingery JM, Maakestad J, et al. Diagnostic pitfalls and laboratory test interference after hydroxychloroquine intoxication: A case report. Toxicol Rep 2019;6:1040-1046.

31- Juurlink DN. Safety considerations with chloroquine, hydroxychloroquine and azithromycin in the management of SARS-CoV-2 infection. David N. CMAJ 2020. doi:

10.1503/cmaj.200528. 


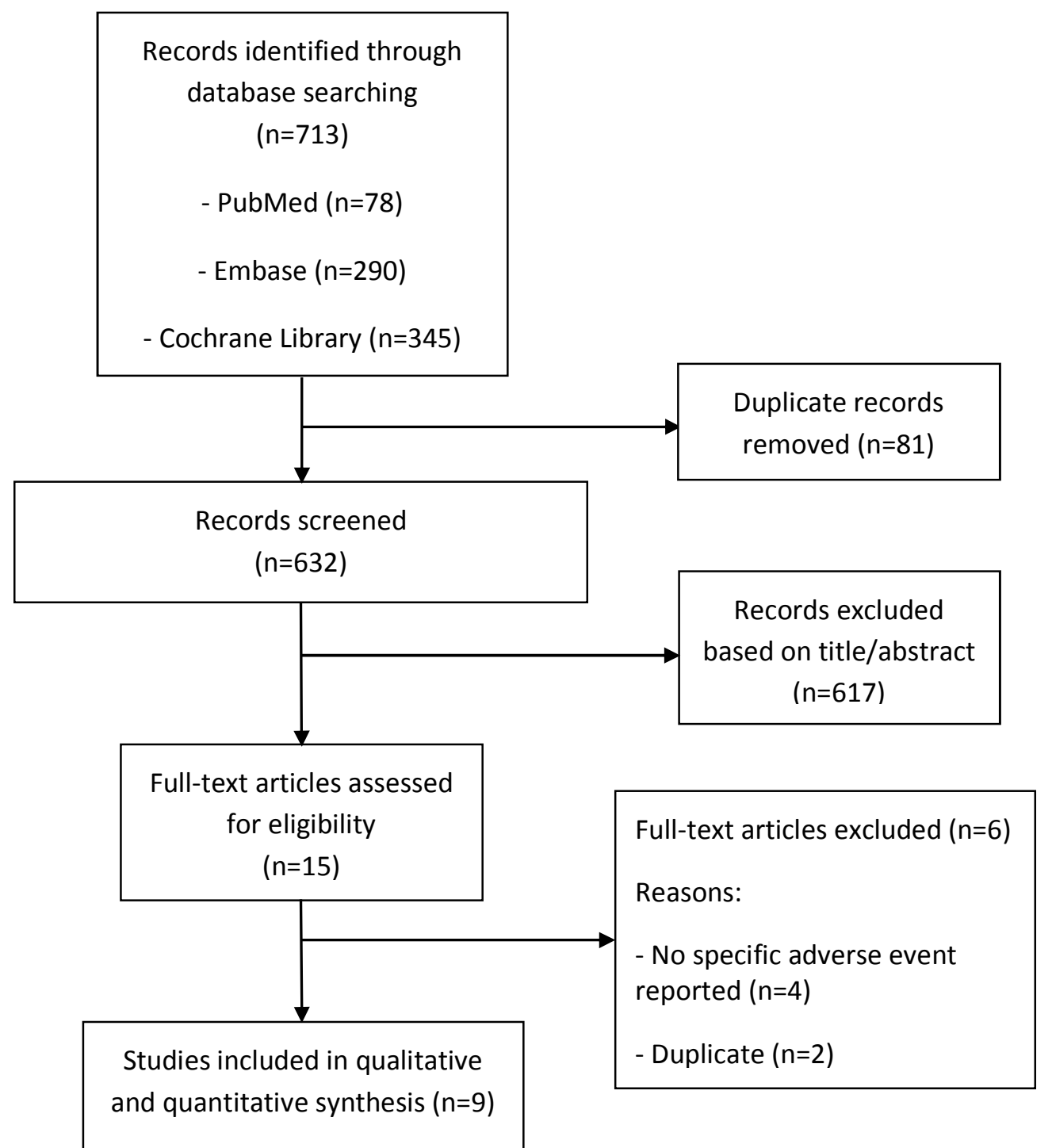

Figure 1 Flowchart of process of literature search and extraction of data from studies meeting the inclusion criteria. 
Table 1. Characteristrics of included studies

\begin{tabular}{|c|c|c|c|c|c|c|c|c|}
\hline Study & Design & Location & $\begin{array}{l}\text { Funding } \\
\text { source }\end{array}$ & $\begin{array}{c}\text { Number } \\
\text { of Patients }\end{array}$ & Age (years) & Indication & $\begin{array}{c}\text { Hydroxychloroquine } \\
\text { Dose }\end{array}$ & $\begin{array}{l}\text { Duration } \\
\text { of therapy } \\
\text { (weeks) }\end{array}$ \\
\hline $\begin{array}{l}\text { Boonpiyathad } \\
2017 \text { [10] }\end{array}$ & $\begin{array}{l}\text { Superiority } \\
\text { single-blind } \\
\text { RCT }\end{array}$ & $\begin{array}{l}1 \text { site in } \\
\text { Thailand }\end{array}$ & $\begin{array}{l}\text { Non- } \\
\text { industry }\end{array}$ & $\begin{array}{c}48 ; \\
24 \text { vs. } 24\end{array}$ & 33 vs. 34 & $\begin{array}{c}\text { Chronic spontaneous } \\
\text { urticaria }\end{array}$ & $400 \mathrm{mg} / \mathrm{day}$ & 12 \\
\hline $\begin{array}{l}\text { Clark } 1993 \\
{[11]}\end{array}$ & $\begin{array}{l}\text { Superiority, } \\
\text { double- } \\
\text { blind RCT }\end{array}$ & $\begin{array}{l}1 \text { site in } \\
\text { Mexico }\end{array}$ & Industry & $\begin{array}{c}121 ; \\
63 \text { vs. } 58\end{array}$ & 39 vs. 36 & Rheumatoid arthritis & $400 \mathrm{mg} /$ day & 24 \\
\hline $\begin{array}{l}\text { HERA Group } \\
1995 \text { [12] }\end{array}$ & $\begin{array}{l}\text { Superiority, } \\
\text { double- } \\
\text { blind RCT }\end{array}$ & $\begin{array}{l}6 \text { sites in } \\
\text { Canada }\end{array}$ & Industry & $\begin{array}{c}119 ; \\
59 \text { vs. } 60\end{array}$ & 53 vs. 53 & Rheumatoid arthritis & $\begin{array}{c}200 \mathrm{mg} / \mathrm{day}, \text { then } 400 \\
\mathrm{mg} / \text { day after } 2 \text { weeks } \\
\text { if tolerated }\end{array}$ & 36 \\
\hline $\begin{array}{l}\text { Kavanaugh } \\
1997 \text { [13] }\end{array}$ & $\begin{array}{l}\text { Superiority, } \\
\text { double- } \\
\text { blind RCT }\end{array}$ & $\begin{array}{l}1 \text { site in } \\
\text { U.S. }\end{array}$ & $\begin{array}{l}\text { Non- } \\
\text { industry }\end{array}$ & $\begin{array}{c}17 ; \\
12 \text { vs. } 5\end{array}$ & Not available & $\begin{array}{l}\text { Systemic lupus } \\
\text { erythematosus }\end{array}$ & $\begin{array}{c}400 \mathrm{mg} \text { and } 800 \\
\mathrm{mg} / \text { day }\end{array}$ & 12 \\
\hline Lee 2018 [14] & $\begin{array}{l}\text { Superiority, } \\
\text { double- } \\
\text { blind RCT }\end{array}$ & $\begin{array}{l}6 \text { sites in } \\
\text { Netherlands }\end{array}$ & $\begin{array}{l}\text { Non- } \\
\text { industry }\end{array}$ & $\begin{array}{c}196 ; \\
98 \text { vs. } 98\end{array}$ & 58 vs. 58 & Osteoarthritis & $400 \mathrm{mg} \mathrm{q} 24 \mathrm{~h}$ & 24 \\
\hline Liu 2019 [15] & $\begin{array}{l}\text { Superiority, } \\
\text { double- } \\
\text { blind RCT }\end{array}$ & $\begin{array}{l}1 \text { site } \\
\text { Finland }\end{array}$ & $\begin{array}{l}\text { Non- } \\
\text { industry }\end{array}$ & $\begin{array}{c}60 ; \\
30 \text { vs. } 30\end{array}$ & 38 vs. 36 & IgA nephropathy & $200 \mathrm{mg} \mathrm{q} 12 \mathrm{~h}$ & 24 \\
\hline $\begin{array}{l}\text { Paton } 2012 \\
{[16]}\end{array}$ & $\begin{array}{l}\text { Superiority, } \\
\text { double- } \\
\text { blind RCT }\end{array}$ & $\begin{array}{l}10 \text { sites in } \\
\text { U.K. }\end{array}$ & $\begin{array}{l}\text { Non- } \\
\text { industry }\end{array}$ & $\begin{array}{c}83 ; \\
42 \text { vs. } 41\end{array}$ & 37 vs. 38 & $\begin{array}{c}\text { Asymptomatic HIV } \\
\text { infection }\end{array}$ & $400 \mathrm{mg} /$ day & 48 \\
\hline $\begin{array}{l}\text { Van Gool } \\
2001[17]\end{array}$ & $\begin{array}{l}\text { Superiority, } \\
\text { double- } \\
\text { blind RCT }\end{array}$ & $\begin{array}{l}4 \text { sites in } \\
\text { Netherlands }\end{array}$ & $\begin{array}{l}\text { Non- } \\
\text { industry }\end{array}$ & $\begin{array}{c}169 ; \\
83 \text { vs. } 86\end{array}$ & 70 vs. 71 & Alzheimer's disease & $\begin{array}{c}200 \mathrm{mg} \text { and } 400 \\
\mathrm{mg} / \text { day }\end{array}$ & 72 \\
\hline $\begin{array}{l}\text { Yokogawa } \\
2017[18]\end{array}$ & $\begin{array}{l}\text { Superiority, } \\
\text { double- } \\
\text { blind RCT }\end{array}$ & $\begin{array}{l}22 \text { sites in } \\
\text { Japan }\end{array}$ & Industry & $\begin{array}{c}103 ; \\
77 \text { vs. } 26\end{array}$ & 43 vs. 43 & $\begin{array}{l}\text { Cutaneous lupus } \\
\text { erythematosus }\end{array}$ & $\begin{array}{c}200 \mathrm{mg} \text { and } 400 \\
\mathrm{mg} / \text { day }\end{array}$ & 16 \\
\hline
\end{tabular}


Table II. Quality assessment of included studies.

\begin{tabular}{|c|c|c|c|c|c|c|c|}
\hline & Select & ion bias & $\begin{array}{c}\text { Performance } \\
\text { bias }\end{array}$ & $\begin{array}{c}\text { Detection } \\
\text { bias }\end{array}$ & $\begin{array}{l}\text { Attrition } \\
\text { bias }\end{array}$ & $\begin{array}{c}\text { Reporting } \\
\text { bias }\end{array}$ & $\begin{array}{c}\text { Other } \\
\text { bias }\end{array}$ \\
\hline Study & $\begin{array}{c}\text { Random } \\
\text { sequence } \\
\text { generation }\end{array}$ & $\begin{array}{c}\text { Allocation } \\
\text { concealment }\end{array}$ & $\begin{array}{l}\text { Blinding of } \\
\text { participants } \\
\text { and } \\
\text { personnel }\end{array}$ & $\begin{array}{c}\text { Blinding of } \\
\text { outcome } \\
\text { assessment }\end{array}$ & $\begin{array}{c}\text { Incomplete } \\
\text { outcome } \\
\text { data }\end{array}$ & $\begin{array}{l}\text { Selective } \\
\text { reporting }\end{array}$ & $\begin{array}{c}\text { Other } \\
\text { bias }\end{array}$ \\
\hline $\begin{array}{l}\text { Boonpiyathad } \\
2017\end{array}$ & $?$ & + & - & - & + & + & + \\
\hline Clark 1993 & ? & ? & + & + & + & + & $?$ \\
\hline $\begin{array}{l}\text { HERA Group } \\
1995\end{array}$ & + & + & + & + & + & + & ? \\
\hline $\begin{array}{l}\text { Kravvariti } \\
2020\end{array}$ & + & + & - & - & + & - & + \\
\hline Lee 2018 & ? & + & + & + & + & + & + \\
\hline Liu 2019 & + & + & + & + & + & + & + \\
\hline Paton 2012 & + & + & + & + & + & - & + \\
\hline $\begin{array}{l}\text { Van Gool } \\
2001\end{array}$ & + & + & + & + & + & + & + \\
\hline $\begin{array}{l}\text { Yokogawa } \\
2017\end{array}$ & + & + & + & + & + & - & $?$ \\
\hline
\end{tabular}

+ , low risk of bias; “?” Unclear risk of bias; “_"” high risk of bias 


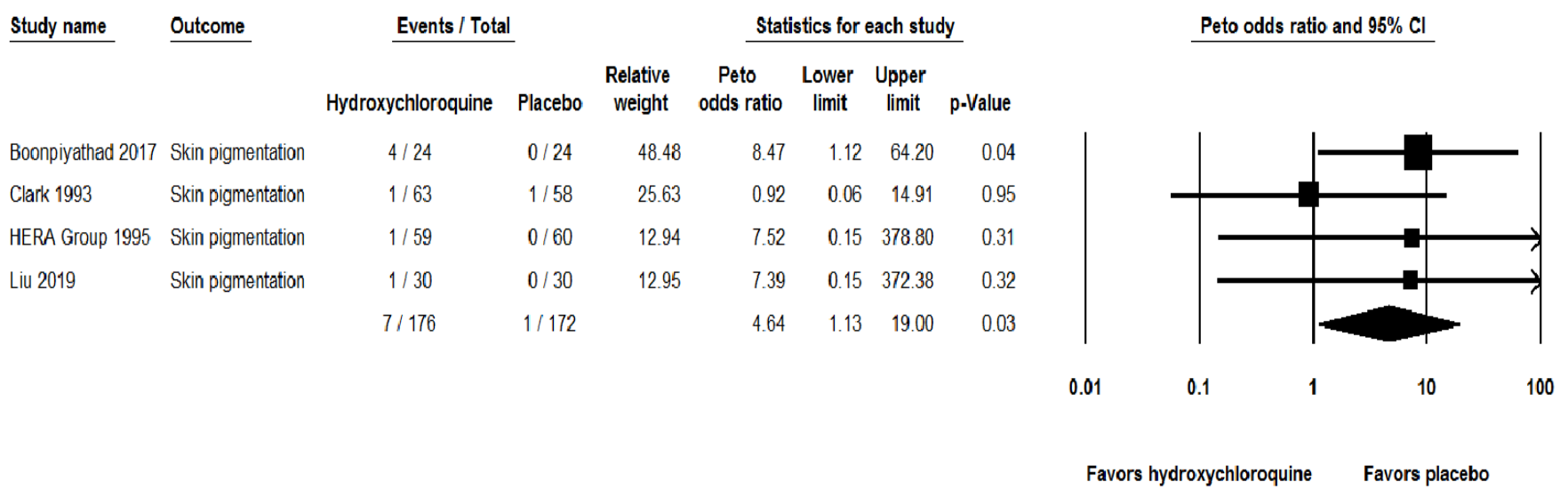

Figure 2 Forest plot showing the Peto odds ratios of skin pigmentation in patients receiving hydroxychloroquine versus placebo. Vertical line, "no difference" point between the 2 groups; horizontal line, $95 \%$ confidence interval; squares, Peto odds ratios; diamonds, pooled Peto odds ratios. 